\title{
A TERÜLETFEJLESZTÉS IRÁNYÍTÁSÁNAK KÉRDÉSEI
} (Issues of the management of regional development)

\section{ILLÉS IVÁN}

\author{
A területfejlesztés, mint a kormányzati politika eleme \\ és az azt meghatározó tényezók
}

A területfejlesztés sajátos aspektusa a gazdaságpolitikának. Valójában magába foglalja a tårsadalom-és gazdaságfejlesztés valamennyi elemét, megtetézve még a térbeli dimenzió differenciáló hatásával. Ezért a területfejlesztési politika semmiképpen sem korlátozható a gazdaságpolitika egyetlen jól definiált és körülhatárolható szegmensére, következésképpen a területfejlesztés irányítása sem korlátozható egyetlen szektorra. Következésképpen a területfejlesztésben nincsenek bevált és elterjedt irányítási struktúrák nemzetközileg sem, az nagy mértékben függ az ország gazdasági rendszerétổ, az irányítás átfogó felfogásától és struktúrájától. Hat fổ tényezổt sorolhatunk fel, amely meghatározza a területfejlesztés helyét és jelentôségét:

- Az ország egészének regionális struktúrája: az ország mérete, az országon belüli gazdasági és népsûrűségi különbségek, a természeti erôforrások megoszlása. Nyilvánvalóan ezek a tényezốk motiválták pl. Szibéria kiaknázásának, vagy Brazília belsổ részeinek hasznosítási politikáját.

- A történelmi, politikai és etnikai tényezốk: egy többnemzetiségû̉ országban - egyéb körülmények azonos volta mellett is - másképp vetổik fel a regionális politika kérdése, mint egy homogén államban. A határok megváltozása — ráadásul e határok ,,nehezen átjárhatóvá" válása - új kihívások elé állítja a regionális politikát: ilyen volt pl. az NSZK határmenti övezeteire, a Zonenrandgebiete-re vonatkozó fejlesztési politika, de újabb regionális problémákat vet fel országok egyesítése, ill. újraegyesítése is.

- Az állami gazdaságpolitika filozófiája és alapcéljai: Alapkérdés természetesen, hogy egy kormányzat milyen jelentôséget tulajdonít a regionális problémáknak, a regionális fejlettségi különbségeknek és ezen belül milyen szerepet szánnak azállami intervenciónak. Szociáldemokrata irányzatú kormányzatok általában nagyobb jelentốséget tulajdonítanak a jövedelem- és esélyegyenlốségnek, és ennek megteremtésében az államnak. Következésképpen a regionális egyenlốtlenségek mérséklésének céljai is nagyobb szerepet kapnak az állami politikában.

- A gazdasági rendszer természetesen döntố tényezô. Kommunista, direkt tervutasításos rendszerben, ahol a piacnak nincs, vagy alig van szerepe, az állam szükségszerûen meghatározó jelentôségử a regionális fejlôdésben, függetlenül attól, hogy ezt közvetlenül vagy közvetve teszi-e. Ugyanakkor a piaci kontroll hiányában a területfejlesztésben politikai szempontok dominálnak. Egészen más a területfejlesztési politika szerepe a piacgazdaságban, még akkor is, ha a kormányzatnak explicit és prioritást élvezô területpolitikai céljai is van- 
nak. Ezeket a célokat ugyanis csak a piac figyelembevételével, közvetítésével, a piaci visszajelzések segítségével tudják elérni.

- Talán az egyik legfontosabb determináló tényezố az állami irányítás, a közigazgatás rendszere:

* szövetségi államokban a föderatív struktúra a közigazgatásnak eleve erôs területi, regionális tagoltságot ad, így a föderatív kormányzás - kimondva, vagy kimondatlanul — az államirányításnak igen erổs területi aspektust kölcsönöz;

* még ennél is fontosabb magának a kormányzati irányításnak a funkcionális tagoltsága: az, hogy az igazgatás elsôsorban ágazati irányultsággal vagy funkcionális jelleggel múködik-e. A központilag irányított tervgazdaságok kivétel nélkül alapvetốen az ágazati irányítási és elosztási elvekre épültek, amiben a területi elv - országonként eltérổ intenzitással és hatékonysággal, - csak kiegészítổ szerepet játszhatott;

* a területfejlesztés szempontjából rendkívül fontos a helyi és területi önkormányzatok rendszere, hatásköre, finanszírozása és pénzügyi forrásai. Ettôl a rendszertôl, hatáskörtôl, hierarchiától és anyagi lehetôségektôll függốen válhatnak az önkormányzatok a területi irányítás fontos, vagy valós hatáskörrel nem bíró periférikus részévé.

- Végül a területfejlesztés nemzetgazdasági helye és irányítása függ az e téren megvalósuló nemzetközi együttmúködéstôl is. Ez természetesen elsôsorban az Európai Közösség regionális politikájára vonatkozik, ahol a közösség bizonyos regionális fejlesztési és támogatási funkciókat átvett a nemzetállamoktól és ezáltal az utóbbiak szerepe természetszerủen módosult.

Tekintettel arra, hogy e hat tényezônek az egyes orszégokban a legkülönbözóbb kombinációi figyelhetốk meg, nem csoda, hogy a területfejlesztés irányításában egységes receptekkel, széleskörû́en elterjedt struktúrákkal aligha találkozunk.

\section{Az elmúlt évtizedek legfóbb tanulságai}

Bár manapság a korábbitól alapjaiban eltérô gazdasági rendszer kiépítése a célunk, mégsem haszontalan az elmúlt negyven év területfejlesztési intézményrendszere fố tanulságainak vázlatos áttekintése:

1. A központi tervgazdál kodású országokban általában, de Magyarországon különösen, a területfejlesztés alapvetốen átpolitizált ügy volt. Jóllehet az egész társadalom- és gazdaságpolitika Magyarországon pártirányítás, párthatározatok alapján müködött, mégis meglepổ - a dokumentumok áttanulmányozása alapján -, hogy a területfejlesztés tekintetében minden lényeges kérdés még részleteiben is határozatokban öltött testet, és a kormányzat e tekintetben meglepố passzivitást, mondhatni csöndes obstrukciót folytatott. Maga a területfejlesztés híres-hírhedt kettôs célja - a hatékonyság és kiegyenlítôdés - is egy ilyen konfliktusos, kompromisszumos megoldást jelzett. A kiegyenlítôdés, vagy közelítés a mindenkori politikai akciókhoz szolgált hivatkozási alapul, a területi hatékonyság pedig — tekintve, hogy annak meghatározására, pláne mérésére, adott feltételek mellett komoly formában soha nem került és nem is kerülhetett sor - a kormányzati bürokrácia részérốl hivatkozásul alapul szolgált e politikai akciók leszerelésére, konkrétabban minden preferenciális vagy diszpreferenciális területfejlesztési eszköz kiiktatására. 
Mi volt az oka ennek, a gazdasági- és társadalompolitika többi eleméhez viszonyítva is nagy politikai túlsúlynak:

— nem utolsósorban az, hogy az MDP, majd az MSZMP szervezeti, irányítási struktúrája eltért a gazdaság általános irányítási struktúrájától. Míg a gazdaságirányításban lényegében az ágazati elv valósult meg, a pártirányításban - mintegy történelmi rekvizitumként - megmaradt a területi elv, azaz annak ellenére, hogy jóllehet a munkahelyi és vállalati pártszervezetek, é\$ nem a lakóhelyiek váltak a politikai és hatalmi tevékenység alapelemévé, ezek továbbra is atelepülési, területi pártbizottságoknaktartoztakelsôsorbanlojalitással, személyükben, pozíciójukban attól függtek. A helyzet természetesen konfliktusos volt, de kétségtelen, hogy a párthierarchiában maradt meg leginkább a területi érdekkinyilvánítás és érdekérvényesítés lehetôsége; - a totalitáriánus monolit egypártrendszer keretében a politikai koncepciók, irányzatok harca lehetetlenné vált, így az elit számára a politizálás egyetlen lehetôsége az ágazati és területi lobbyzás volt. Az ágazati lobbyzásnak azonban megvolt a maga kézenfekvổ irányítási, miniszteriális és ezáltal intern csatornája, így a szó szorosabb értelmében vett politikai tevékenység terepévé - ha ilyesmirốl egyáltalában beszélhetünk - a területi lobbyzás vált, többek között ez képezte a megválasztott képviselốk túlnyomó többségének kizárólagos tevékenységét.

2. A területfejlesztésnek egyfajta politikai, ill. propagandisztikus jelentôsége tehát mindvégig megmaradt a negyven év alatt. Jóllehet a kormányzat e követelményeknek deklaratív szintẹn általában igyekezett is eleget tenni, sốt mindez a minisztériumok, fổhatóságok között folyó presztizs és hatalmi harc állandósult témájává is vált, valójában az e téren folyó kormányzati tevékenységnek a dolgok folyamatára való tényleges ráhatása közvetlenül minimális volt, a küzdelmek fiktív pozíciókért folytak. Nem állítom, hogy a területfejlesztési politika a gazdasági szerkezetre semmiféle hatást nem gyakorolt, de ami volt, az sokkal inkább politikai és párt nyomásgyakorlás, semmint kormányzati tevékenység alapján jött létre.

Mi volt az oka a területfejlesztés, mint kormányzati tevékenység e teljes periferizálódásának és hatástalanságának?

- Mindenekelốtt az irányítás általános alapelve és struktúrája. A rendszer eredeti változatábłan teljes egészében az ágazati , tervlebontás” elve alapján múködött, azaz a Tervhivataltól a minisztérium, a minisztériumtól a vállalat, a vállalattól a gyáregység kapta az összes anyagi eszközeit, a részletezett feladatokat és ugyanezen csatornán visszafelé tartozott elszámolni tevékenységével. Késốbb a direkt tervlebontás megszűnt, de a rendszer alapvonásai fennmaradtak. Ebben a redszerben egyszerủen nem volt hely semmiféle területi elvû́ koordinációnak, pláne irányításnak, azt, mint immunrendszer a szervezetidegen tevékenységet, kivetette magából; — Az 1962. évi vállalatátszervezés, majd az 1968. évi irányítási-rendszer reform még tovább korlátozta a területfejlesztés kormányzati hatókörét. A nagy országos vállalatok létrehozása ugyanis a területfejlesztést végsôsoron vállalaton belüli üggyé tette, az 1968. évi reform pedig a vállalaton belüli ügyeket valójában kivonta a kormányzat hatókörébôl. Ezután a vállalatok maguk döntötték el - meghatározott adminisztratív korlátok, pl. a budapesti telepítési tilalom keretein belül -, hol hoznak létre új ipartelepet, illetve melyik ipartelepet fejlesztik, melyiket nem. A kormányzat ezt pénzügyi szabályozókkal némileg befolyásolhatta;

- Végsốsoron ez az eszköz, a pénzügyi szabályozás, lehetett volna és kellett volna, hogy legyen egy piacgazdaságban a területfejlesztés irányításának legfởbb kormányzati eszköze. Itt mutatkozott meg leginkább a területfejlesztés periférikus szerepe az 1968 utáni területfejlesztési 
irányításban. Abban ugyanis, hogy a kormányzati irányítás és a pénzügyi irányítás nem volt hajlandó érdemben integrálni a területfejlesztési differenciákat, vagy egyáltalán regionális szempontokat érvényesíteni. A maximum, ami elérhetô volt, az az állam által nyújtott vállalati beruházási támogatások egy részének területfejlesztési célra való felhasználása. Ennek összege idổnként kisebb, idônként nagyobb volt - a politikai szituációtól függôen -, de sohasem haladta meg a GDP 1-2 ezrelékét. Ezt valójában mindig politikai kényszerek nyomása alatt adott alamizsnaként értékelték.

Az adórendszer térbeli differenciálása elleni érvelés fố pontja mindig a normativitás, az egységesség megốrzése volt. Valójában ez igaz is lett volna, ha a gyakorlatban nem áltt volna vele szemben sok száz kivétel az ágazati és vállalati szintư szabályozóalkuk eredményeként. A másik érv volt a gyáregység, ipartelep szintjén a mérleg és szintetikus kimutatások hiánya, ami ismét igaz volt, legfeljebb ott sántított az érvelés, hogy eközben sokkal idôrablóbb és feleslegesebb kimutatások százait készíttették el a vállalatokkal. Valójában ez is inkább a pénzügyi kormányzatnak a területi problémák iránti teljes érzéketlenségét, és kevésbé az objektív akadályokat demonstrálta;

- Végül az irányítás ágazati rendszere illuzórikussá tette a középsố szintnek, a megyei tanácsoknak, az átfogó területfejlesztésben való részvételét is. A megyei tanács ugyanis sajátos képzôdmény volt. Az infrastrukturális ágazatok egy része esetében - amelyek hatókörébe tartoztak - ki volt ugyan szolgáltatva a minisztériumok, a tervhivatal diktátumainak, de nagy hatalommal és önállósággal rendelkezett az így juttatott összegek települések közötti elosztásában. Az ágazatok másik, nagyobb - nem felügyeleti körébe tartozó - csoportjában azonban sem információ nem volt a fejlesztési szándékokról, sem lehetôség, eszköz, hatáskör annak bárminemú befolyásolására. A „,megyei területfejlesztési tervek” elkészítésének elrendelése és azok elkészítése tehát már-már komikus erôfeszítés és tevékenység volt. A kormányzat elrendelt olyasmit, amiről tudta, hogy nem lehet teljesíteni, hiszen az adott területen müködổ gyáregységek, ipartelepek maguk sem tudtak semmit saját jövôjükrốl, fejlôdésükrôl, a központi nagyvállalat pedig egyszerũen nem tekintette partnernek a tanácsot, még akkor sem, ha magának a nagyvállalatnak volt valami elképzelése a jövốrốl, ami az idô elốrehaladtával egyre kevésbé volt jellemzố.

3. Az elmúlt 40 év területfejlesztésrốl szóló elemzéseiben, tanulmányaiban kevésbé kapott hangsúlyt egy momentum, amelynek pedig rendkívüli a jelentôsége. Nevezetesen arról van szó, hogy az elemzốk a területfejlesztést és településfejelsztést egy kalap alá vették, vagy az utóbbit az elsố részének tekintették, és így a területfejlesztésre vonatkozó bármely értékítélet automatikusan kiterjesztổdött a területfejlesztésre is. Pedig, ha az egyik - a területfejlesztés - alatt a gazdaság és a társadalom térbeli szerkezetének kormányzati segédlettel való megváltoztatását, az utóbbi - a településfejlesztés - alatt pedig a települések nagyságának és infrastrukturális állapotának - ugyancsak kormányzat révén, de a kormányzatok közvetítésével való változását értjük, akkor a kettô között a magyar gazdaságirányításban alapvetổ különbség volt:

Magyarországon a területfejlesztés funkcióján az Országos Tervhivatal és az Építésügyi és Városfejlesztési Minisztérium osztozkodtak, ill. vitatkoztak, annál hevesebben, minél kevesebb volt a valós hatáskör és funkció mögötte, és azt hiszem, hogy ez így is logikus. A területfejlesztés funkcióin viszont a Tervhivatal (egy másik részlege), a Pénzügyminisztérium és a Mi- 
ni\$ztertanács Tanácsi Hivatala osztozott, nem konfliktusok nélkül, de azért együttmúködve és munkamegosztásban (az elsô gondoskodván a fejlesztésról, a második az üzemelésről, a harmadik a közigazgatási szevezetrốl, a belsố igazgatási struktúrákról, várossá nyílvánításról stb.). Mig a területfejlesztés - mint mondtuk - az irányítási rendszerbe nem illeszkedett bele, azon kívül állt, a területfejlesztés szervesen integrálódott a rendszerbe. Beépült ugyanis az ágazati irănyítás rendszerébe, a Tervhivatalban egyetlen részlegben összpontosítva a teljes infrastruktúrafejlesztést: lakás, közmû́, helyi közlekedés, oktatás, egészségügy, kultúra, sport stb., ami măs minisztériumokban szétszórva helyezkedett el, és mindezt összefogva a tanácsi, települési fejlesztés keretében.

Ráadásul ezt a tanácsi és infrastrukturális irányítást és szabályozást az 1968-as reform szele alig érintette. A döntések, az eszközök elosztása továbbra is központilag , lebontva” történt. Következésképpen igen nagy hatalom és felelősség koncentrálódott ezen emberek kezében.

Nem véletlen, hogy ezek a gyökeresen eltérô feltételek két gyökeresen eltérổ emberfajtát , termeltek ki" a két terület állami irányításában. A területfejlesztés megfelelố pozícióiban olyan emberek gyültek össze, akik magas felkészültséggel, tudományos fokozattal rendelkeztek, a témáról számos értekezést és publikációt jelentettek meg (csupán néhány nevet említve: Kơszegi László, Kóródi József, Boros Ferenc, Bartke István, Tatai Zoltán, Lackó László), de valós befolyásuk az elosztási folyamatokra alig, vagy nem volt. Néhányan beletörődtek, néhányan - széplelkek lévén - észre sem vették, míg mások szélmalomharcot folytattak. A területfejlesztés, a tanácsi irányítás kulcspozícióiban viszont megbízható bürokraták ültek, akik egy-két tiszteletreméltó kivételtôl eltekintve - tudományos és publikációs tevékenységet nem folytattak, megelégedtek azzal a hatalommal és elismeréssel, amit hivatali pozíciójuk juttatott nekik. Nem véletlen, hogy az elmúlt évtizedek területfejlesztési publikációi többnyire apparátuson belülrôl, településfejlesztési publikációi apparátuson kívülról (Szelényi Iván, Konrád György, Enyedi György, Vági Gábor) és azok kritikájaként jelentek meg.

Lényegében ugyanez a helyzet a megyei tanácsokkal. Mint jeleztük, az átfogó területfejlesztésben valójában semmiféle lehetôséggel nem rendelkeztek (aki tehát ezt ma helyre akarná állítani, az nem létezố dolog életrekeltésével kísérletezik). Ezzel szemben - különösen a hetvenes évtizedben - döntổ befolyásuk volt a településfejlesztésre, vagyis arra, hogy a megye településeli az erôforrásokból milyen arányban részesedtek, milyen fejlôdési pályát tehettek meg.

E cikk keretei nem alkalmasak arra, hogy a településfejlesztési politika erényeit és hibáit, sốt vétkeit itt elemezzem. Csupán arra hívom fel a figyelmet, hogy míg a területfejlesztés, a térségi, regionális gazdasági arányok és struktúrák millió ágazati és vállalati döntés együttes hatásaként jöttek létre, addig a településfejlesztés fổ arányaira vonatkozó döntések egy-két tucat eniber kezében öszpontosultak, akik azonosíthatóak, érdemeik nem vehetốk el, és felelốsségük nem hárítható át.

\section{A jelenlegi helyzet és a teendók}

Többszörösen is igazolható, hogy ma a területfejlesztés nehezebb, bonyolultabb és sürgősebb feladatok elốtt áll, mint a megelốzố fél évszázadban bármikor:

1. Ez döntốen a megváltozott objektív gazdasági helyzet következménye: 
- Az általános és nagyarányú gazdasági recesszió nyilvánvalóan területileg differenciáltan érvényesül. Törvényszerû, hogy az újonnan, kevésbé szilárdan megalapozottan, a helyi gazdaságba beépülten létrejött gazdasági egységek, ipartelepek válnak elsôként áldozatává a gazdasági válságnak, különösen akkor, ha sorsukról a döntés egy távoli központ kezében van;

- A külgazdasági reorientáció, a keleti piacok összeomlása az e piacokra elsôsorban ráépült keleti országrészeket sújtja, míg a nyugati mû́ködốtốke, bérmunka és kooperáció elsốsorban - és érthetốn - a nyugati országrészeknek válik előnyére. Egyértelmúen - és a korábbiakban soha nem tapasztalt mértékben - kibontakozik az ország gazdasági szint alapján történổ kettészakadása;

- A piacgazdaság térnyerésével a piaci tényezôk, a földrajzi, gazdasági környezet differenciáltságából adódó járadékdifferenciák egyre inkább teret kapnak és tovább növelik a különbséget. Valójában a piac differenciáló hatása területi értelemben csak most kezd érvényesülni;

- Végül újfajta és egyelôre átláthatatlan függốségi rendszerek kezdenek kialakulni. Kül földi és hazai cégek felvásárolnak, vagy ellenőrzô részesedést szereznek más vállalatokban, néha fejlesztési, néha nem egészen belátható más célok érdekében. Egyelôre még távolról sem tudható, mik lesznek e láthatatlan érdekeltségi és irányítási hálónak a regionális konzekvenciái.

2. Egyidejû̉leg megszûntek azok a politikai érdekérvényesítési intézmények és struktúrák, amelyek a területi szempont, a területi érdek valamilyen szintủ megjelenítését és érvényesítését szolgálták:

— Eltûnt az állampárt a maga területi szervezetével, hierarchiájával és hatalmával. A mai területi (megyei) pártszervezetek közül egyik sincs - még ha szándékában lenne is - olyan pozícióban, hogy akár saját pártjában, de még kevésbé az országos politikában, a területi érdeket érvényesítse.

- Megváltozott a parlament összetétele. A képviselók jelentôs része országos listákon, de másik jelentôs része sem egyéni választókerületbôl, hanem pártja jóvoltából került a parlamentbe. De általában is - a politikai tevékenység színterének jelentổs kiterjedésével - a képviselơk tevékenységét sokkal inkább a pártküzdelmek és csak sokadrangúan a területi lobbyzás köti le;

- Ha nem is a megyei pártbizottságokhoz hasonló, de mégis erôs hatalmi központot, érdekérvényesítési lehetôséget jelentettek a megyei tanácsok a kormányzati szférában. Az új önkormảnyzati rendszer azonban a megyét korábbi hatalmi pozíciójától teljesen megfosztotta, azok megszûntek a kormányzati politikára bármilyen érdemi hatást gyakorolni.

Félreértés ne essék, a szerzốtôl mi sem áll távolabb, mint a pártállami struktúrák , visszasírása”. Csupán ténymegállapításként szögeztem le, hogy e struktúráknak volt - sok egyéb és nem kívánatos fukció mellett - bizonyos, nem elhanyagolható, térségi területi érdekérvényesítô funkciója is, és ezek a funkciók akkor szûntek meg, amikor a területi problémák soha nem látott mértékben kiélezôdtek. És egyenlôre semmi sem jött létre helyettük.

3. Mindebbôl fó következtetésként és logikusan az adódik, hogy az átmenti idôszakban a kormányzaton belül kell egy igen erốs területfejlesztési funkciót és irányítást kiépíteni. Két megjegyzés kívánkozik ehhez:

- a nemzetközi - fóleg európai - területfejlesztési irányzatok ma, a hatvanas-hetvenes évekkel szemben, inkább egy állami redisztribúció ellenes, a helyi kezdeményezésekre, eróforrásokra, az innovációra, a múszaki fejlesztésre orientált politikát preferálnak, amelynek legjobb szintetizálása talán Walter Stöhr professzor mưveiben jelenik meg. Érthetó reakciója ez 
a korábbi évtizedek területfejlesztési politikájának egyes kudarcaira. Miközben azonban ezen új irányzatok minden hasznosítható elemét alkalmazni kell, nem lehet elfeledkezni arról, hogy a magyar gazdaság ma a mintául vett országoktól gyökeresen eltérố helyzetben van. Ezek az új irányzatok kiépült és erôs magánszektoron, fejlett piacgazdaságon, kiépült és intenzív helyi piaci kapcsolaton alapulnak, és nem ilyen rohamosan visszafejlődô gazdaságokra dolgozták ki, mint a magyar gazdaság. Ezért, miközben ezeket az eszközöket és intézményeket már most tölrekednünk kell alkalmazni, ma Magyarországon nélkülözhetetlen - a redisztribúció elemeit is tartalmazó és nem csupán a keretrendszerre, vagy az infrastruktúrára korlátozódó - határozфtt kormányzati területfejlesztési politika érvényesítése:

- A másik megjegyzés az MSZP regionális politikára vonatkozó beterjesztett törvénytervezetéhez kapcsolódik. E törvénytervezet, azzal az indokolással, hogy a regionális politika mindenkit érint és mindenhez kapcsolódik, azt kvázi kivenné a kormányzati hatáskörbốl és parlamenti, helyesebben a parlament alá rendelt Tanács, vagy Bizottság hatás- és feladatkörébe helyezné. Úgy gondolom, hogy ez a javaslat — bármi is legyen a vélemény a mai, vagy mindenkori kormányzatokról - nem járható. A területfejlesztés az átfogó társadalom- és gazdaságpolitika része, és abból kiszakítva - netán avval szembeállítva - garantáltan teljesen hatástalanná válik. Az elmúlt évtizedek bôséges példát szolgáltatnak erre vonatkozóan.

4. A kormányzatnak tehát - véleményem szerint - kiemelt szerepe kell legyen. Ehhez képest a mai kormányzati területfejlesztési politika gyakorlata inkonzisztens, rögtönzó és làssú:

- Mindeddig nem kerültek kidolgozásra a kormányzati területfejlesztési politika alapirányai, alapelvei, koncepciója. A munkálatok elsôsorban a területfejlesztési törvény kidolgozására koncentrálódtak. Véleményem szerint azonban a politika alapelveinek kidolgozása elsốdleges a törvényi szabályozással szemben, és ennek hiányában legfeljebb nyugati - nem a mi kỏrülményeinkhez illeszkedô - törvényszövegek adaptálására, vagy terméketlen hatásköri és intézményi vitákra kerülhet sor;

- A területfejlesztést érintố intézkedések rögtönzô, ad hoc és tûzoltó jellegûek. Az egyes megyékre vonatkozó programok kidolgozására kihelyezett kormányülések nyomán, vagy szüksẹghelyzetben kerül sor, és a felelốs kormányszerv megjelölése meglehetósen rögtönzött jellegứnek tưnik. Így pl. Szabolcs-Szatmár-Bereg megye felzárkóztatási koncepciójának kormányzati kezelését a belügyminiszter, Nógrád megye kezelését az ipari és kereskedelmi miniszter, Baranyáét a környezetvédelmi és területfejlesztési miniszter, Borsod-AbaújZemplénét a pénzügyminiszter, az ún. kistérségi programokat a munkaügyi miniszter kapta meg feladatul. Az egyik legjelentốsebb program indítása egy képviselổi indítványt követô országgyủlési határozat alapjản történt: az Alföld rövid- és hosszú távú területfejlesztési és tảjhasznosítási koncepciójáé. Ez korábban a kormányzati munkaprogramban semmiféle formában nem szerepelt, ezt követôen szerves és kiemelt részévé vált. Az ötletet adó képviselổ történetesen kormánypárti volt, és az embernek el kell gondolkodnia, ugyanígy alakulnak e a munkaprogramok, ha ugyanez az ötlet történetesen egy ellenzéki képviselổnek jut eszébe.

5. A területfejlesztési és településfejlesztési funkciókat továbbra is - nem egészen tisztázott munkamegosztásban - több tárca látja el, és úgy tủnik megismétlôdnek, újratermelốdnek az elmúlt évtizedek áldatlan helyzetei és konfliktusai; 
- Elốször van az országnak a területfejlesztést nevében is viselố minisztériuma: a KTM. Úgy tû̉nik azonban, hogy ez a minisztérium fontosságában, hatáskörében, szavának súlyában, de fốleg rendelkezésre álló eszközeiben nem tartozik az ,,elsôrangú” minisztériumok közé, ami természetesen hatással van az egész területfejlesztési problémakör érdekérvényesítési lehetôségeire is;

- A Belügyminisztérium látja el az önkormányzatokkal, valamint a területfejlesztéssel összefüggó feladatokat, ugyan ezekben a funkciókban, és a területfejlesztésben jelentôss feladatai vannak a Pénzügyminisztériumnak is. Mindkét minisztérium mind a hatalmi és presztizshierarchiában, mind a rendelkezésre álló anyagi eszközökben lényegesen jobban áll, mint a Környezetvédelmi és Területfejlesztési Minisztérium. A baj az, hogy e minisztériumokon belül a terület- és településfejlesztés ügye nem tartozik az elsôrangú kérdések közé, mi több, periférikusnak számít. Hiába tehát a minisztérium jelentôs kormányzati súlya, ha azt nem veti be a területfejlesztés érdekében;

- Megörökölte a két minisztérium - a KTM és a IBM - az áldatlan hatásköri vitát, ami olykor nyílt sajtópolémiában is kifejeződik (ld. Morvay István cikke a Magyar Hírlapban), de még a minisztériumokon belüli vita is nyît konfliktussá válik (pl. amikor Szabó Gábor helyettes államtitkár a KTM-beli lemondását részben a területfejlesztés , túlzott” térnyerésével indokolja). De a BM-en és PM-en belül sem teljes az információs és intézkedési összhang a területtelepülésfejlesztési és egyéb részlegek között). Megismétlődni látszik az a szituáció is, hogy a KTM-ben a területfejlesztés irányításában egyénileg kiváló teljesítményt nyújtó kutató szakemberek gyülekeznek, de államigazgatási gyakorlat és valós hatáskör nélkül, míg a területfejlesztés irányítását és a velejáró jogi és pénzügyi hatásköröket a BM-ben - ismét bizonyos kivételekkel - derék bürokraták veszik kézbe;

- A belsổ viták és minisztériumi presztizsharcok miatt valós kormányzati koordináció e kérdésben nem tud kialakulni. A tárcaközi koordináció érdekében 1991. júniusában létrehozták a Gazdasági Kabinet Regionális Munkabizottságát, mint tárcaközi szervet. A munkabizottságot azonban 1991. szeptember után össze sem hívták. A területfejlesztési törvény elōterjesztése - egyeztetési problémák, valamint a parlament zsúfolt napirendje miatt - 1992-ben sem szerepel az Országgyúlés napirendjén, jóllehet azt már egy éve elổ kívánták terjeszteni.

De nemcsak a kormánynak nincs területfejlesztési elgondolása, hanem az ellenzéknek sem. Az MSZP törvénytervezetét már említettem. Úgy tû̉nik, hogy az SZDSZ és a FIDESZ eddig fel sem fogta a területi problémák súlyát, vagy ha igen, akkor is fontosabbnak tartja e téren a kormányzati (ill. köztársasági megbízotti) akciók, valamint a megyei önkormányzatok befolyásának korlátozását, mint a problémák megoldását. E pártokban a vidéki szervezetek, a területi érdekképviselet súlya még kisebb, mint a koalíció pártjaiban és az MSZPben.

A leírtak szándéka tehát távolról sem csak és nem is elsôsorban a kormányzat kritikája akar lenni, hanem figyelemfelhívás arra, hogy a dolgok aggasztóan állnak: az országos munkanélküliségi ráta 10 százalék, de vannak községek, ahol 10 százalék azok aránya, akiknek munkája van. Együttes cselekvésre van szükség a helyzet javítására. 
6. A legfontosabb, legsürgốsebb teendổ tehát a kormányzat kötelezettségeinek, feladatainak đs hatáskörének meghatározása, ill. megerösítése a területfejlesztésben.

- Mindenekelốtt határozott és egyértelmú területfejlesztési program - törvénnyel együ̈t, yagy anélkül - elkészítése szükséges, amely hitet tesz a kormányzat aktív szerepvállalása mellett a területi válságproblémák megoldásában. Arra hivatkozni, hogy ez az eredeti kormányprogramban benne van komolytalan, hiszen amióta az elkészült, csupán olyan változások játszódtak le, hogy megszủnt a Szovjetunió, megszû̉nt (Nagy-) Jugoszlávia, az ipari termelés a felére esett vissza, és a munkanélküliek száma gyakorlatilag nulláról 600 ezerre nốtt;

- A területfejlesztésnek egységes és erôs kormányzati képviseletre van szüksége. A tapasztạlatok szerint egy ilyen nevû, de szükségszerủen periférikus szerepû̉ minisztérium ennek csak a látszatát biztosítja, még akkor is, ha ott szakmailag kiválóan felkészült emberek tevékenykednek ezen az ügyön. A magyar történelmi hagyományok és a tényleges hatalmi helyzet alapján ez a helyzet leginkább a Belügyminisztériumban biztosítható, jóllehet ennek ott is számos szakmai és személyi feltétele lenne (pl. a minisztérium szervezeti struktúrájának megváltoztatása, a civil jelleg további erôsítése, a szakmai, személyi és tudományos háttér megerôsítése), de legfớképpen az, hogy ezt az ügyet a kormányzat és a minisztérium vezetése is magáénak vallja és elsôrangú ügyként kezelje;

- A területi válság, az átlagosnál súlyosabb területi recessziók kezeléséhez természetesen pénz kell. 1991-rốl 1992-re a Területfejlesztési Alap összege 1,5 milliárdról 6 milliárdra (a GDP 0,2 százalékra) nổtt. Elsô látásra ez tekintélyesnek látszik, valójában csak látszat. Belefoglalták ugyanis a kedvezổtlen adottságú területek 4 milliárdos - korábban agrárszubvenciónak tekintẹt — támogatását, továbbá eltöröltek mintegy 0,5 milliárd értékú adókedvezményt. Valójában az összeg tehát nominálértékben legfeljebb változatlan, reálértékben természetesen jelentôsen csökkent, miközben a területi problémák lényegesen súlyosbodtak. Ha a nyugat-európai országoknak csak a minimálnormáját kívánnánk elérni, a területfejlesztési célú támogatást akkor is a GDP 1\%-ára, azaz a mai arány ötszörösére kellene emelni. A mai csôdök és felszámolások tởmege figyelmeztet továbbá arra, hogy egy egyszeri támogatás kidobott pénz, ha kedvezốtlen fẹltételek között nem biztosítjuk a folyamatos jövedelemtermelés és forrásképzés minimális feltểeleit. A régi rendszer beruházási támogatása tehát nem elegendô, e területeken bizonyos folyamatos adókedvezmények elengedhetetlenek. A pénzügyi bürokrácia ellenállásával szemben is be kell tehát építeni a regionális szempontokat a pénzügyi szabályozórendszerbe. Különösen fontos továbbá, hogy a külföldi befektetốk az ország keleti és általában válságos, elmaradott területein különleges kedvezményben részesüljenek.

7. Végül, de egyáltalán nem utolsósorban, felmerül a területi érdekérvényesítés politikai, gazdasági és társadalmi problémája:

- Egyik megoldásként felmerülhet a kétkamarás parlament, ahol az egyik kamarában a képviselốk - politikai tagoltságban ugyan, de - nem utolsósorban területeket, megyéket, régiókat képviselnének. Félổ azonban, hogy ez nem lesz egyszerû́ dolog, s hogy e második kamarában oly sok érdeket kívánnának megjelentetni (pl.: munkáltatók - munkavállalók), hogy a területi érdekérvényesítés végülis elsikkadna;

- A másik megoldás az erổs és reprezentatív térségi-területi önkormányzatok rendszere. A nyolcvanas évekig , ,középerốs” szinten - annak sok hátrányával és elônyével, de nem igazán reprezentatív, demokratikus alapon — ez létezett Magyarországon, az 1989-90-es tárgyalások 
ill. alkotmányozás során, a kormánypártok és a liberális ellenzék közösen, ezt a szintet lényeges funkcióitól megfosztotta. Valamilyen térségi érdekérvényesítési középszint hiánya tehát nyilvánvaló. De az is nyilvánvaló, hogy a köztársasági megbízotti ,,régiók” nem azok, hiszen a nyugat-európai regionalizálás alulról fölfelé, a központi kormányzatok hatalmának és kompetenciájának korlátozására választott testületekkel - sok helyen választott kormányzatokkal jött létre. Nálunk fordítva, felülrôl lefelé, a kormányhatalom helyi képviseleteként, mindenfajta testület, helyi érdekstruktúra, reprezentáció nélkül alakultak e szervek. De legyen szó akár megyérôl, akár régióról - azok elônyeinek és hátrányainak vitatása meghaladná e tanulmány kereteit - a lényeg az, hogy a választott alapú erôs térségi önkormányzatok a hatékony területfejlesztési politika politikai és társadalmi elôfeltételeit képezik. 


\section{ISSUES OF THE MANAGEMENT OF REGIONAL DEVELOPMENT}

\section{IVÁN ILLÉS}

At present, regional development is facing far more difficult, complicated and urgent problems than any time before during the last 50 years.

In the first place, it is the consequence of new, objective economic conditions:

- Overall and extensive economic recession exerts its influence in a regionally differentiated way. It is unavoidable, that new economic units, which have no solid foundations, and are integrated into the local economy, are the first victims of economic crisis, especially when their future is decided at far-away headquarters;

- Re-orientation of foreign trade and the collapse of Eastern markets primarily jeopardize the Eastern parts of the country which had been oriented to these regions. At the same time, Western operating capital, commission work and cooperation understandably favour and promote the development of the Western parts of the country. The separation of the country on the basis of economic development is clearly and excessively becoming a characteristic feature;

- With the market economy gaining ground the market factors, are gaining importance, and with the increasing differentiation of the economic factors the differences in allowances and taxes are becoming increasingly characteristic, and they all add to the increase of differences. In effect, the differentiating factors of the market only start to exert their influence in regional sense and terms. but their final influence and consequences are unknown as yet;

- Finally, new and yet incomprehensible systems of dependencies begin to develop. Hungarian and foreign companies buy up other companies or get a majority share in them, sometimes for the purpose of development, and sometimes for other reasons.

Parallel with it, all those systems and structures that were created for safeguarding the interests at certain regional levels have disappeared (the state party with its regional organization, the county councils, etc. have all ceased to exist).

The logical consequence stemming from this is that in the transitional period, a strong function and management for regional development has to be created within the government. At present in Hungary the prevailance of a well-determined governmental regional development policy containing the elements of redistribution, but not being limited to the fundamental system or the infrastructure, is absolutely necessary.

Consequently, the government has to be given a special role. As opposed to this, the actual practise of government regional development policy is inconsistent, slow and unplanned. The basic directions, fundamental principles and the concept of government regional development policy have not been elaborated as yet. Measures on regional development are ad hoc, and of fire-fighting character.

The functions of regional and settlement development are still fulfilled by different portfolios and have no clear distribution of tasks. 
As a consequence, the most urgent thing to do is to determine the obligations, duties, tasks and spheres of influence of the government in regional development. As a first step, a clear and well-defined regional development programme - with or without legislation - has to be elaborated. Regional development requires strong and uniform representation by the government.

And last, but not least, the political, economic and social problems of the representation of interests at regional level should be solved. One of the solutions could be a parliament with two houses, where the representatives of one of the houses would represent regions, counties, etc. The other solution could be the system of strong and representative regional local governments.

Translated by J. Mészáros

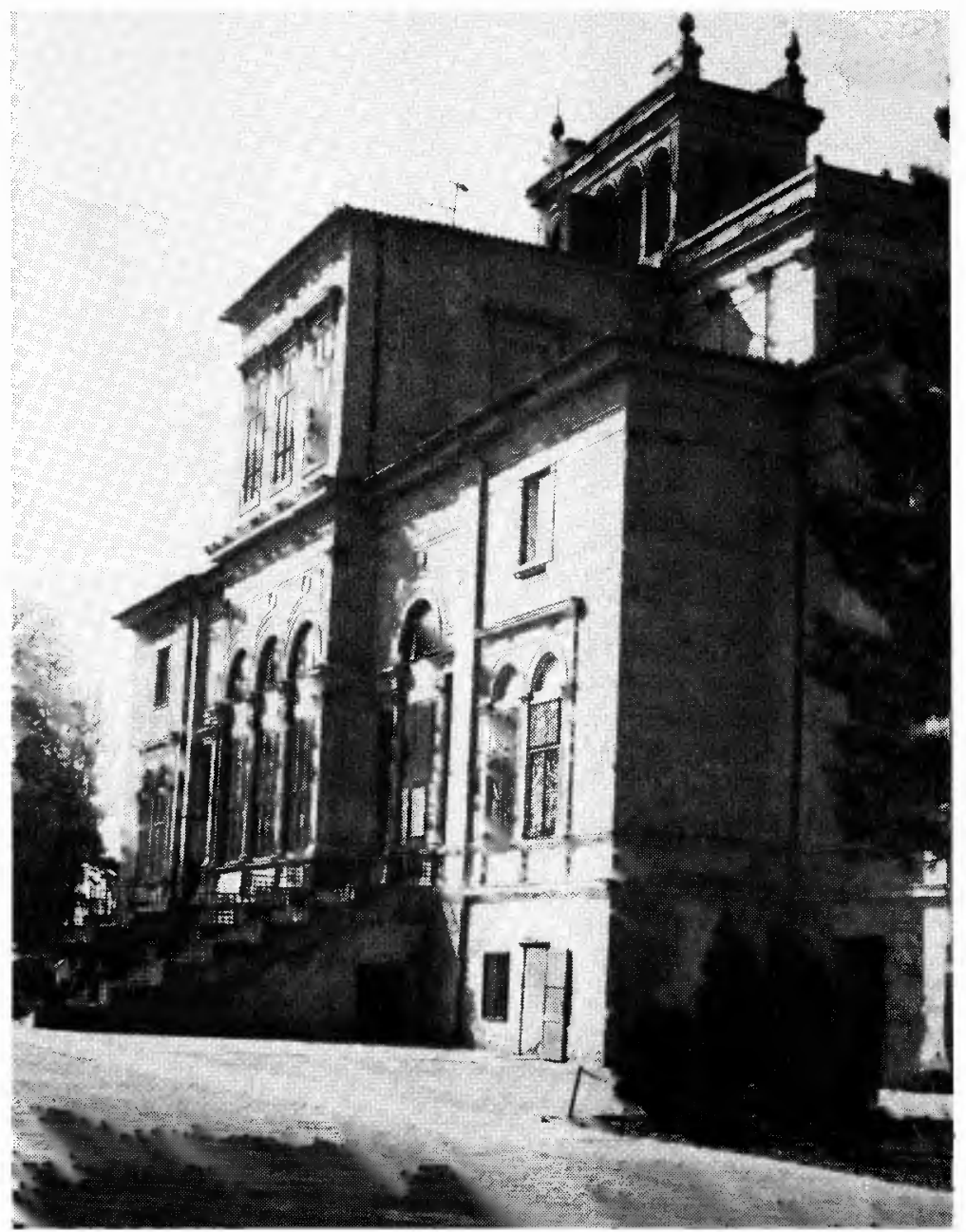

